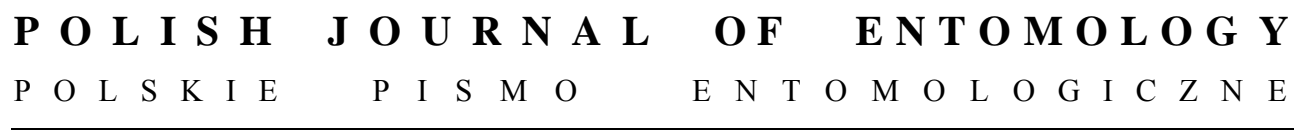

VOL. 80: $535-545$

Gdynia

30 September 2011

DOI: $10.2478 / \mathrm{v} 10200-011-0042-\mathrm{z}$

\title{
Revision of the Neotropical genus Tsinilla HEINRICH (Lepidoptera: Tortricidae)
}

\author{
JÓZEF RAZOWSKI ${ }^{1}$, VITOR O. BECKER ${ }^{2}$ \\ ${ }^{1}$ Institute of Systematics and Evolution of Animals, Polish Academy of Sciences, \\ Sławkowska 17, 31-016 Kraków, Poland; \\ ${ }^{2}$ Reserve Serra Bonita, PO Box 01, 45880-970 Camacan, BA, Brasil
}

\begin{abstract}
Neotropical species of Tsinilla known to date are listed, and 14 species are discussed, five of which (T. basirufa sp. n., T. merana sp. n., T. rhopos sp. n., T. kilastra sp. n., T. roseonigra sp. n.) are described as new. Argyroploce impolita MEYRICK and Olethreutes isopercna MEYRICK are transferred to Tsinilla.
\end{abstract}

KEY WORDS: Tortricidae, Olethreutinae, Tsinilla, new species, Neotropics.

\section{INTRODUCTION}

Tsinilla HeINRICH, 1931 was described from Florida (U.S.A.) and was long regarded as a monotypic genus. RAZOWSKI \& WOJTUSIAK (2008) found three new Neotropical species. We now realize that Tsinilla is rich in species and widely distributed in this region. Some species, earlier described by MEYRICK in Argyroploce and then placed by CLARKE (1958) in Olethreutes and treated by BROwN (2006) as "unplaced Olethreutinae" or "unplaced Olethreutini", are now placed in this genus. All known species differ externally from the type species and could easily be overlooked.

All the specimens were collected by the junior author; the types of the newly described species are preserved in the Becker Collection, Camacan, and will ultimately be deposited in one of the Brazilian Museums. Some spare specimens have been kindly donated to the Institute of Systematics and Evolution of Animals, PAS, Kraków.

Note. The numbers cited on the labels of the type material are the entry numbers of the specimens in the register of the above-mentioned collection. Abbreviation: GS - genitalia slide. 


\section{Acknowledgements}

The authors thank Mr. Witold Zajda, Kraków, for taking the photographs of the genitalia and arranging the plates and Mr. Krzysztof Fiokek for the photographs of the adults.

\section{SYSTEMATICS}

\section{Tsinilla HEINRICH, 1931}

Tsinilla HeInRICH, 1931, Proc. U.S. Natn. Mus.,79: 14; Type species: Eucosma lineana Fernald, 1901.

\section{List of known species}

albidecora RAZOWSKI \& WoJTUSIAK, 2008, (Tsinilla), Ecuador; female genitalia. basirufa sp. n., Ecuador; male genitalia. cataphracta (MEYRICK, 1917) (Olethreutes), British Guiana; ClARKE 1958: 366; male and female genitalia. circumplexa (MEYRICK, 1922) (Argyroploce); male genitalia. heliophanes (MEYRICK, 1922) (Argyroploce), Peru; ClARKE 1958: 516 (Olethreutes); male genitalia.

impolita (MEYRICK, 1917), (Argyroploce), Colombia; ClaRKE 1958: 520 (Olethreutes); male genitalia. Comb. n.

isopercna (MEYRICK, 1927), (Argyroploce), Colombia, ClaRkE 1958: 524 (Olethreutes), this paper: male genitalia. Comb. $\mathbf{n}$.

kilastra sp. n., Ecuador; female genitalia. lineana HeINRICH, 1931 (Tsinilla), U.S.A.: Florida, male genitalia. merana sp. n., Ecuador; female genitalia. rhopos sp. n., Brazil; female genitalia. roseonigra sp. n., Brazil; male and female genitalia. sardiodes (MEYRICK, 1922), (Argyroploce), Peru; CLARKE 1958: 544 (Olethreutes); male genitalia. tristis RAZOWSKI \& WOJTUSIAK, 2008, (Tsinilla), Ecuador, male genitalia. ubericolor RAZOWSKI \& WOJTUSIAK, 2008, (Tsinilla), Ecuador, male genitalia.

\section{Species examined}

\section{Tsinilla basirufa sp. $\mathbf{n}$.}

(Figs 1, 11)

\section{Diagnosis}

This species is close to $T$. sardiodes but $T$. basirufa has a large dark brown subterminal fascia of the forewing, a pale rust-coloured wing base, a slender uncus and large socii. 


\section{Description}

Wingspan $15 \mathrm{~mm}$. Head and thorax brownish, labial palpus more cream. Forewing not expanding terminad; costa convex; apex broadly rounded; termen straight medially. Ground colour whitish in the form of many dots between dark brown reticulation of antemedian and postmedian interfasciae. Costal strigulae small, whitish; divisions large, brown. Markings: basal blotch large, cream ferruginous indistinctly dotted cream; dorsal part of median fascia darker, its remaining parts dark brown, diffuse reaching tornus; subterminal fascia large, broadening towards termen, followed by a rust-coloured apical area. Cilia worn. Hindwing brown, remnants of cilia similar (Fig. 11).

Male genitalia (Fig.1). Uncus fairly long, moderately broad basally then distinctly tapering apicad; socius large, oval; valva slender with weak neck; single spine at angle of sacculus; cucullus rather short with distinct spine at ventral lobe; aedeagus slender.

Female not known.

\section{Material examined}

Holotype male: "Ecuador: Napo, Misahualli 450 m, XII 1992, V.O. Becker Col; Col. Becker 102225"; GS 726.

\section{Etymology}

The name refers to the colouration of the forewing; Greek: basis - base, Latin: rufa rust.

\section{Tsinilla cataphracta (MEYRICK, 1917), comb. $\mathrm{n}$.}

(Figs 2, 5, 12)

Olethreutes cataphracta MeYrick, 1917, Trans. Ent. Soc. London, 1917: 25. T.1.: Bartica, British Guiana. ClARKE 1958: 366 (Olethreutes).

\section{Description}

Wings of male as in Fig. 12.

Male genitalia (Fig. 2). Uncus elongate, slender basally, rounded apically; socius small; valva slender, broadest basally, neck weak; small ventral prominence marked by group of spines of which one is long, before ventral lobe of cucullus; the latter with two unequal spines; long seta from beyond mid-costa of valva; aedeagus short.

Female genitalia (Fig. 5, not known until now). Sterigma small with well developed cup-shaped part and small, membranous posterior portion of postostial part; sclerite of antrum large, fused with cingulum; one slender signum present.

\section{Material examined}

Two males from Pará, Brazil (Capităo Poco, 28-31 I 1984).

\section{Tsinilla circumplexa (MEYRICK, 1922), comb. $\mathrm{n}$.}

Argyroploce circumplexa MeYrick, 1922, Exotic Microlepid., 2: 523. T.1.: Parintins, Brazil. Clarke 1958: 496 (Olethreutes). BROWN 2006: 447 (Oletheutini Unplaced). 


\section{Comments}

Based on the illustration by CLARKE, this species is closely related with cataphracta, from which it differs in the whitish posterior third of the forewing and the densely spined proximal edge of the cucullus.

Tsinilla heliophanes (MEYRICK, 1922), comb. n.

Argyroploce heliophanes MeYrick, 1922, Exotic Microlepid., 2: 523. T.1.: Iquitos, Peru; ClARKE 1958: 516 (Olethreutes); BROwN 2006: 447 (Olethreutinae Unplaced).

\section{Comments}

Judging from the illustrations by CLARKE (1958), this species belongs in Tsinilla. It shows a similar facies and genitalia most similar to roseonigra.

\section{Tsinilla impolita (MEYRICK, 1917), comb. n.}

Argyroploce impolita MeYrick, 1917, Trans Ent. Soc. London, 1917: 28. T.1.: San Antonio, Colombia. Clarke 1958: 520 (Olethreutes). Brown 2006: 447 (Olethreutinae Unplaced).

\section{Comments}

ClARKE (1958) illustrated this species, but the depiction of its male genitalia is not sufficiently clear to determine whether it is conspecific with ubericolor. The valva is much broader and the uncus slenderer.

\section{Tsinilla isopercna (MEYRICK, 1927), comb. n.}

(Fig. 4)

Argtyroploce isopercna MeYRICK, 1927, Exotic Microlepid., 3: 340. Clarke 1958: 524 (Olethreutes). Brown 2006: 447 (Olethreutinae Unplaced).

\section{Material examined}

One specimen from Costa Rica (Volcan Turrialba, 1800 m, 13 VIII 1972).

\section{Description}

Male genitalia (Fig. 4). Uncus broad basally, triangular postmedially; socius rounded; valva long with slender neck and distinct ventral incision followed by a rather short cucullus and large pulvinus.

\section{Remarks}

This species is illustrated by CLARKE (1958), but the male genitalia are deformed, hence the illustration is unclear. This species was described from San Antonio, Colombia.

\section{Tsinilla kilastra sp. $\mathbf{n}$.}

(Figs 8, 15)

\section{Diagnosis}

This species is close to cataphracta and roseonigra but kilastra has a small pale costal 
forewing blotch fused with the subterminal interfascia; the female genitalia are similar to cataphracta but in kilastra the signum and sterigma are broader with the posterior edge of the cup-shaped part incised medially.

\section{Description}

Wingspan $17 \mathrm{~mm}$. Head and thorax dark blackish brown. Forewing as in roseonigra. Ground colour brownish cream slightly mixed pink at costa, consisting of subterminal interfascia extending from costa to tornus; postmedian part of dorsum tinged rust, remaining area dark brown with numerous bluish dots. Costal strigulae atrophied. Cilia brown. Hindwing brown; cilia paler, more greyish (Fig. 15).

Male not known.

Female genitalia (Fig. 8). Cup-shaped part of sterigma almost uniformly broad throughout with shorter ventral part, the distal edge of which incised medially; sclerite of antrum long, fused with cingulum; anterior half of ductus bursae membranous; signum moderate.

\section{Material examined}

Holotype female: "Cuba: S[an]t[ia]go, Sier.[ra] Maestre 1500 m, P. Cuba, 31 VI 1990, V.O. Becker; Col. Becker 73598"; GS 1315.

\section{Etymology}

The name refers to the forewing colouration: Greek: kilo (chilioi) - thousand, Greek/Latin: aster - star

\section{Tsinilla lineana HEINRICH, 1931}

\section{Material examined}

Several specimens from Mexico (El Ensina, Tamaulipas 250 m, 4-13 VIII 1988; S. Tiago, Tuxtla, Veracruz 800 m, 30 X-2 XI 1973; Biol. Station Los Tuxtlas, 11-16 VI 1981, Veracruz); one specimen from Cuba (Matanzas, Cienag, Zapata, 18 VIII 1990).

\section{Remarks}

This species was described from Florida, U.S.A. It is widely distributed as it is found in Mexico and Venezuela. Two specimens from Costa Rica (Turrialba $600 \mathrm{~m}, \mathrm{X} .1971$ ) and Brazil (Acailandia, Maranhăo 150 m, 19-27 XI 1990) differ from the typical specimens in the facies and the uncus. At present we are unable to evaluate these characters.

\section{Tsinilla merana sp. $\mathbf{n}$.}

\section{Diagnosis}

(Figs 6, 13)

This species is close to kilastra and cataphracta but merana has an almost completely suffused bluish grey posterior interfascia of forewing and a rather well sclerotized postostial sterigma. 


\section{Description}

Wingspan $18 \mathrm{~mm}$. Head and thorax blackish brown, labial palpus paler, greyer. Forewing as in cataphracta but with more convex termen. Ground colour brownish, in posterior area pale, hardly tinged pinkish; interfasciae bluish grey, base of wing with some concolorous spots; costal strigulae cream, very small; apex rust-coloured. Markings dark brown with some paler, brownish parts, typical of the genus. Cilia brown. Hindwing dark brown, paler basally; cilia concolorous with middle of wing (Fig. 13).

Male not known.

Female genitalia (Fig. 6). Sterigma fused with subgenital sternite, rather well sclerotized posteriorly, with short cup-shaped part; sclerite of antrum long, fused with cingulum; signa two, one blade-shaped, the other flat with two tips of which one is long. Subgenital sternite elongate, with terminal parts connected beyond sterigma.

\section{Material examined}

Holotype female: "Ecuador: Past[asa] Mera 1300 m, XII 1992, V.O. Becker Col.; Col. Becker 100706"; GS 710.

\section{Etymology}

The specific name refers to the type locality.

\section{Tsinilla rhopos sp. $\mathbf{n}$.}

(Figs 7, 14)

\section{Diagnosis}

Very closely related and similar to merana, but rhopos has a strong projection of posterior edge of the median fascia and a short, broad subterminal fascia, a short cingulum, and lateral curved sclerites on the subgenital sternite.

\section{Description}

Wingspan $14 \mathrm{~mm}$. Head and thorax black-brown, tegula with refractive marks. Forewing as in merana but costa straighter medially. Ground colour brownish, widely suffused bluish grey except for whitish postmedian shade along costa and white edge of subterminal interfascia; basal area spotted bluish; apex of wing and costal part of termen dark rust-brown. Markings black-brown, posterior edge of median fascia with short median projection; subterminal fascia reduced to rounded median blotch. Cilia brown, rust-brown in costal half basally. Hindwing brown; cilia somewhat paler (Fig. 14).

Male not known.

Female genitalia (Fig. 7). Subgenital tergite rather long with posterior parts broadly fused medially; sclerite of antrum longer than cingulum; signa two.

\section{Material examined}

Holotype female: "Brazil: R[io de]J[aneiro], Nova Friburgo 800 m, 22 I 1993, V.O. Becker Col; Col. Becker 86033"; GS 722.

\section{Etymology}

The name refers to the smaller size and slight differences in comparison with maerana; Greek: rhopos - a trifle. 


\section{Tsinilla roseonigra sp. $\mathbf{n}$.}

(Figs 3, 9, 16)

\section{Diagnosis}

Closely related with cataphracta but roseonigra has a subapical pale blotch extending towards the end of the termen; the base of the uncus is very broad, the apex of the uncus has a slender process, and the subterminal part of the neck of the valva has a large group of spines. The sterigma and sclerites of the ductus bursae of roseonigra are larger than those of cataphracta.

\section{Description}

Wingspan $18 \mathrm{~mm}$. Head and thorax black-brown, labial palpus with whitish marks. Forewing as in cataphracta. Ground colour pinkish cream suffused brown. Markings blackish brown: Basal blotch indistinct, diffuse; median fascia extending in middle ventrally and terminally; subterminal fascia preserved in middle, connected by a suffusion with median fascia. Large whitish pink blotch beyond median fascia extending in form of pinkish grey interfascia to end of termen; costal strigulae indistinct; divisions brownish, apex brown. Cilia worn. Hindwing brown, remnants of cilia similar (Fig. 16).

Female wingspan $21 \mathrm{~mm}$; forewing darker than in holotype.

Male genitalia (Fig. 3). Base of uncus very broad, rounded laterally, remaining part of uncus broad, rounded posteriorly with small apical process; socius fused with uncus lobes; valva rather broad to $1 / 3$; neck moderate with small median prominence with fine, long spines, and a few hairs; cucullus rather short with pollex armed with two spines; aedeagus moderate, slightly bent.

Female genitalia (Fig. 9). Postostial sterigma membranous medially, with slender transverse posterior sclerite; lateral and proximal parts sclerotized; sclerite of antrum long, fused with cingulum at proximal edge, where ductus seminalis originates; one spiniform signum present.

\section{Material examined}

Holotype male: "Brasil: M[inas]G[erais] 1400 m, Cerra do Cipo, 17-19. IV. 1991, V.O. Becker Col; Col. Becker 78170"; GS 750. Paratype female, same label; GS 749.

Tsinilla sardiodes (MEYRICK, 1922), comb. $\mathbf{n}$.

Argyroploce sardiodes Meyrick, 1922, Exotic Microlepid.,2: 523. T.1.: Iquitos, Peru. Clarke 1958: 544 (Olethreutes), type illustrated. BROWN 2006: 448 (Olethreutinae Unplaced).

\section{Comments}

Transferred to Tsinilla on the basis of illustrations by CLARKE (1958). Facies similar to T. circumplasia; male genitalia resemble those of T. basirufa. 

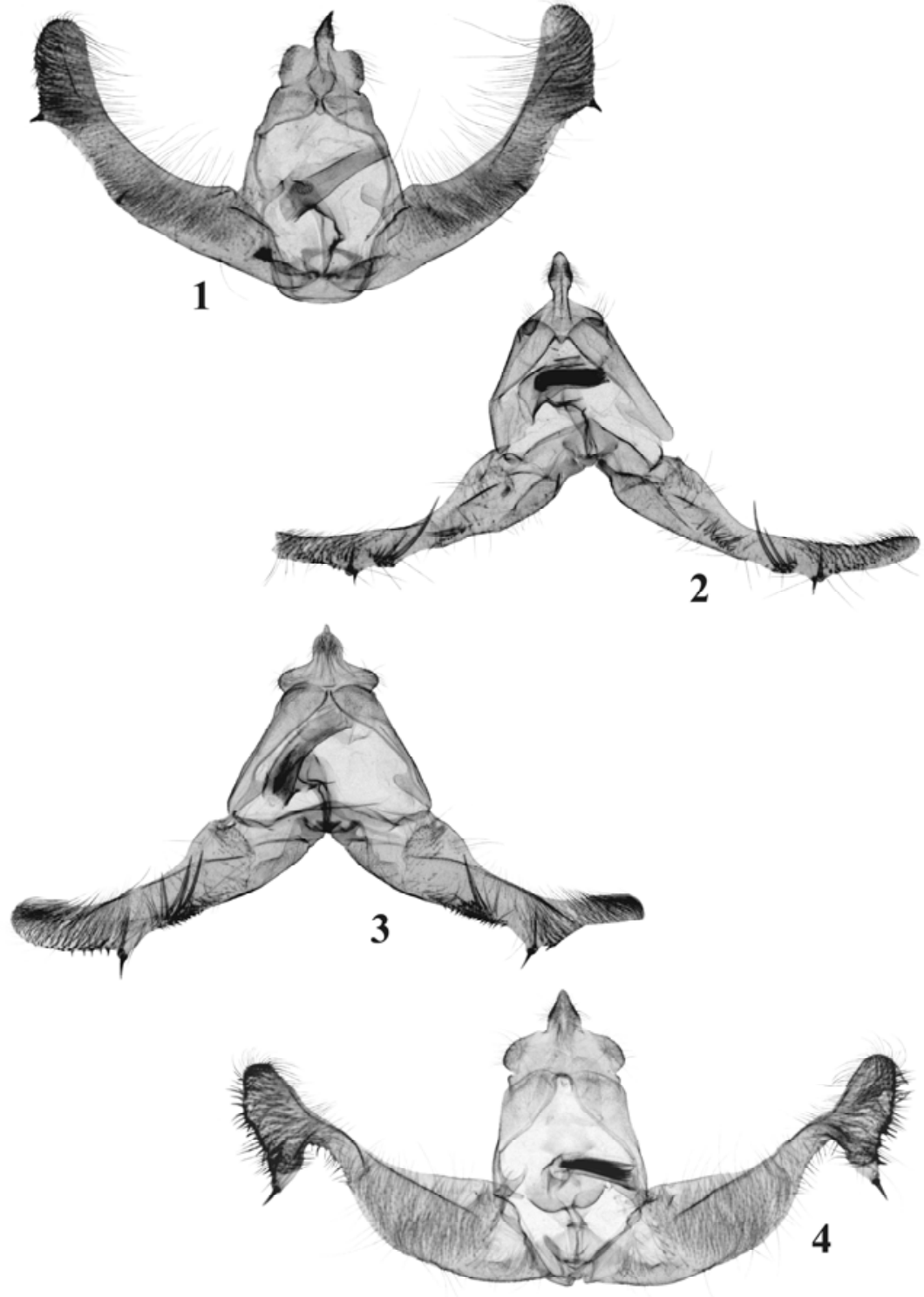

Figs 1-4. Male genitalia of Tsinilla HeINRICH: $1-T$. basirufa sp.n. holotype, $2-T$. cataphracta (Meyrick), Pará, Brazil, 3 - T. roseonigra sp. n., holotype, 4 - T. isopercna (MEYRICK), Turrialba, Costa Rica. 

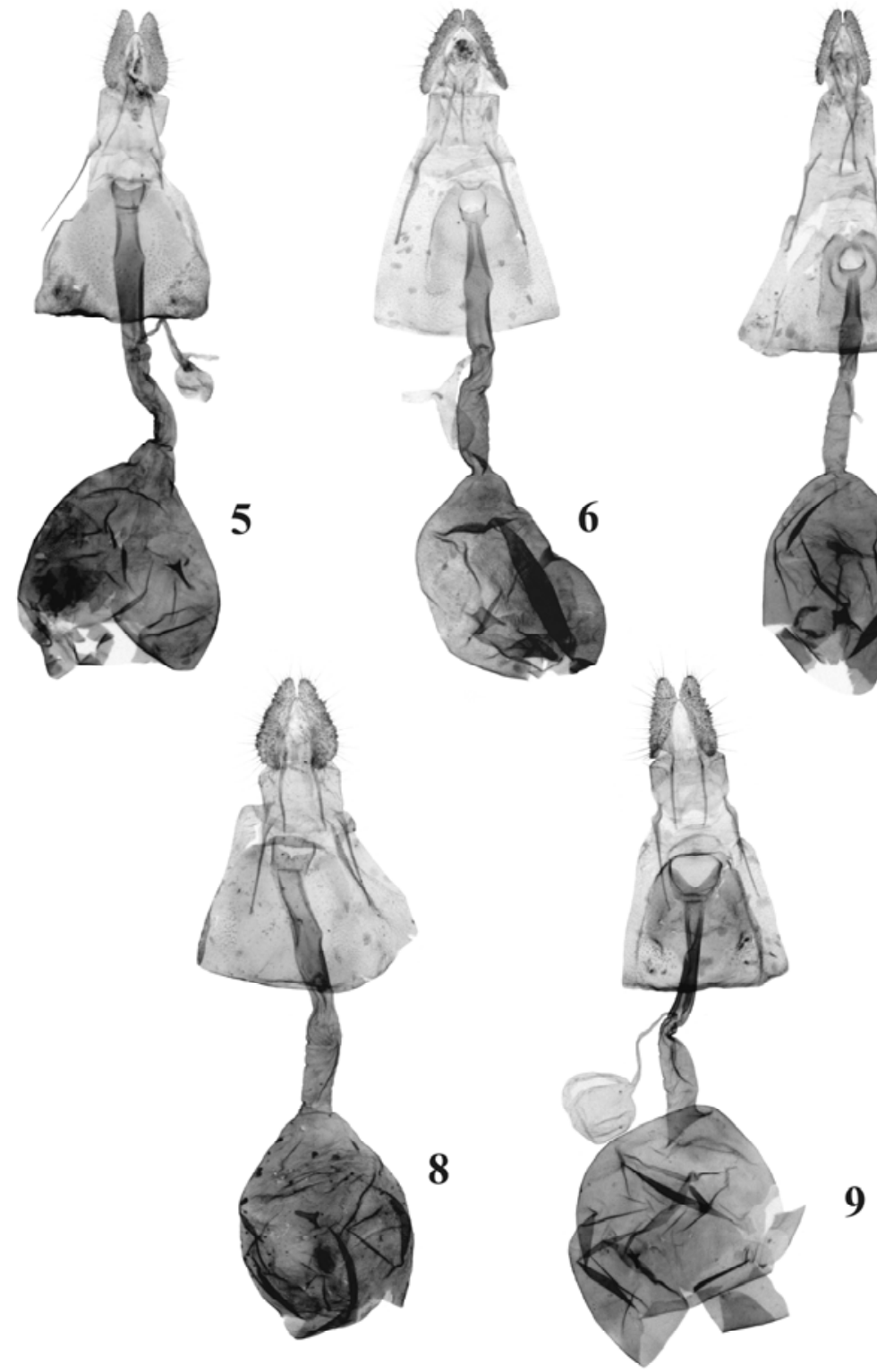

Figs 5-9. Female genitalia of Tsinilla HeInRICH: 5 - T. cataphracta (MeYrick), Pará, Brazil, 6 - T. merana sp. n., holotype, $7-$ T. rhopos sp. n., holotype, $8-$ T. kilastra sp. n., holotype, $9-T$. roseonigra sp. n., paratype. 


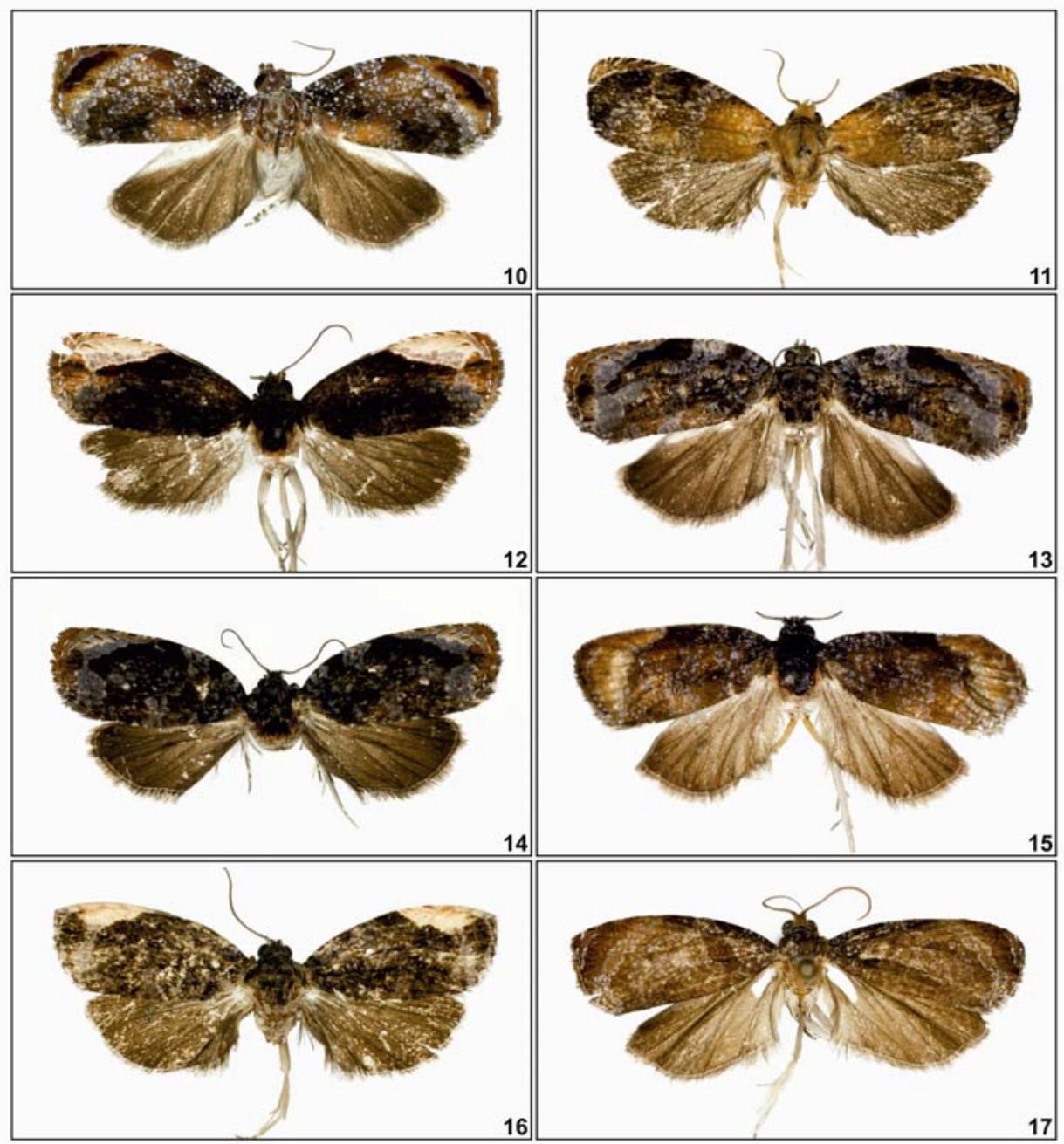

Figs 10-17. Adults of Tsinilla HeInRICH: $10-$ T. tristis Razowski \& WoJTUSiaK, Minas Gerais, Brazil, 11 - T. basirufa sp. n., holotype, 12 - T. cataphracta (MEYRICK), Pará, Brazil, 13 - T. merana sp. n., holotype, $14-$ T. rhopos sp. n., holotype, $15-$ T. kilastra sp. n., holotype, $16-T$. roseonigra sp. n., paratype, 17 - T. isopercna (MEYRICK), Turrialba, Costa Rica.

Tsinilla tristis RAZOWSKI \& WOJTUSIAK, 2008

(Fig. 10)

\section{Material examined}

Three specimens from Minas Gerais, Brazil (Caraca 1300 m, 1-2 IV 1992). 


\section{Comments}

T. tristis was described from the males collected in the province of Pichincha, Ecuador at an altitude of $1150 \mathrm{~m}$.

\section{Tsinila ubericolor RAZOWSKI \& WOJTUSIAK, 2008}

\section{Material examined}

One specimen from Ecuador: Carchi (Maldonado, 1200 m, 9-11. I. 1993). Described from the same province from an altitude of $2000 \mathrm{~m}$. See also the comments relating to impolita.

\section{REFERENCES}

Brown J.W. 2006. Tortricidae (Lepidoptera). World Catalogue of Insects 5, 741 pp.

Clarke J.F.G. 1958. Catalogue of the type specimens of Microlepidoptera in the British Museum (Natural History) described by Edward Meyrick. III. London, British Museum, 600 pp.

RAzOWSKi J., WoJTUSiaK J. 2008. Tortricidae from the mountains of Ecuador. Part III: Western Cordillera (Insecta: Lepidoptera). Genus 19: 497-757.

Received: January 19, 2011

Accepted: June 05, 2011 